Article

\title{
Study on the Construction of 3D Geological Model of Quaternary Loose Sedimentary Strata Based on the Global Stratigraphic Discrete Points
}

\author{
Jixiang Zhu ${ }^{1,2}{ }^{\circledR}$, Yan Lu ${ }^{1}$, Guanghui Zhang ${ }^{1, *}$, Xiaoyuan Zhou ${ }^{1}$ and Guangjun $\mathrm{Ji}^{1}$ \\ 1 Institute of Hydrogeology and Environmental Geology, Chinese Academy of Geological Sciences, \\ Shijiazhuang 050061, China; hellozjx@126.com (J.Z.); luyan@mail.cgs.gov.cn (Y.L.); \\ zxiaoyuan@mail.cgs.gov.cn (X.Z.); jiguangjun@mail.cgs.gov.cn (G.J.) \\ 2 Key Laboratory of Groundwater Sciences and Engineering, Ministry of Natural Resources, \\ Shijiazhuang 050061, China \\ * Correspondence: zhangguanghui@mail.cgs.gov.cn
}

Citation: Zhu, J.; Lu, Y.; Zhang, G.; Zhou, X.; Ji, G. Study on the Construction of 3D Geological Model of Quaternary Loose Sedimentary

Strata Based on the Global

Stratigraphic Discrete Points. Water 2022, 14, 75. https://doi.org/

$10.3390 / w 14010075$

Academic Editor: Achim A. Beylich

Received: 3 December 2021

Accepted: 29 December 2021

Published: 2 January 2022

Publisher's Note: MDPI stays neutral with regard to jurisdictional claims in published maps and institutional affiliations.

Copyright: (C) 2022 by the authors. Licensee MDPI, Basel, Switzerland. This article is an open access article distributed under the terms and conditions of the Creative Commons Attribution (CC BY) license (https:// creativecommons.org/licenses/by/ $4.0 /)$.

\begin{abstract}
Accurately depicting the spatial structure characteristics of Quaternary loose sedimentary strata is not only of great significance for the research of Quaternary geological evolution, but also for the analysis of spatial variation characteristics of the inner hydrogeological and engineering geological attributes of the strata. In this study, an approach for constructing a 3D geological model of Quaternary loose sedimentary strata is proposed based on global stratigraphical discrete points. The approach obtains the discrete control point set of each stratum by using limited borehole data for interpolation and encryption, and the contact relationships and intersection modes of adjacent strata can be determined via the analysis of stratigraphic sequence; finally, taking these as the professional basis, the construction of the 3D geological model of Quaternary loose sedimentary strata can be carried out. This application can not only accurately describe the three-dimensional spatial distribution characteristics of the Quaternary loose sedimentary strata, it can also be used to perform a layered simulation of the spatial variation characteristics of the inner geological properties of the Quaternary loose sedimentary strata, such as lithology, porosity, and water content, by taking the three-dimensional spatial framework of each stratum as the simulation boundary. Finally, this study takes the citizen center of Xiong'an new area as an example in order to verify the reliability and advancement of the 3D geological modeling scheme.
\end{abstract}

Keywords: quaternary sedimentary strata; stratum structure; global stratigraphic discrete points; 3D geological modeling; geological simulation

\section{Introduction}

The Quaternary loose sedimentary stratum is one of the most important places for human survival [1,2], and its spatial structural variation controls the internal engineering of geological [3] and hydrogeological [4,5] characteristics which are of great significance for infrastructure [6,7], prevention of geological disasters [8], and groundwater safety $[9,10]$. Therefore, much literature has focused on research related to the spatial structure, sedimentary genesis, and paleogeographic environment of Quaternary sedimentary strata, etc., and the main technical methods include Quaternary drilling [11-13], geophysical interpretation [14-16], the isotopic method [17-19], granulometric analysis [20-22], etc. The Quaternary sedimentary strata have always been one of the key points of urban geological survey and research $[23,24]$.

However, two issues may arise from technical schemes that directly analyze the sedimentary characteristics of Quaternary loose strata based on locally limited data. The first is there is never enough data $[25,26]$, especially for large-scale Quaternary geological research; 
the second is that Quaternary loose strata, which include deposits from various sedimentary sources, possess complicated spatial structural characteristics [27,28], especially with respect to the origin of continental deposits. Hence, directly studying the sedimentary characteristics of Quaternary loose strata using locally limited data results in a large degree of uncertainty [29].

3D geological modeling is an ideal solution to these issues [30-32]. Høyer et al. [33] constructed a 3D geological model using AEM resistivity data; Lau et al. [34] established a 3D geologic model to research the structure of Quaternary deposits; Chen et al. [35] constructed a 3D stochastic model to simulate the characterization of the internal attributes of sedimentary strata; Erharter et al. [36] developed a 3D stochastic model to represent the sediment bodies; and there are also many technical approaches, such as machine learning, that have been applied to optimize the construction of 3D geological models, especially when fractures and fracture networks are involved [37-39]. While the research mentioned above has presented excellent approaches for determining the spatial structure or inner attributes of Quaternary loose sedimentary strata, they mainly focused on the 3D visual interpretation of boreholes [40] and geochemical data [41] (mainly seismic data [42,43]), or $3 \mathrm{D}$ simulation on a small scale with a strict hypothesis, and there are few reports on the relevance of the construction of 3D geological models of Quaternary loose sedimentary strata based on identifying the spatial distribution in the whole study area by deep mining little pieces of Quaternary geological field data.

In this study, an approach for constructing a 3D geological model of Quaternary loose strata on the basis of global stratigraphic discrete points is proposed. Firstly, the global control point set of each stratum is obtained by establishing the geostatistical model based on the Quaternary geological field data; then, the contact relationships and intersection modes of the adjacent strata are determined, which are applied as the professional basis for the 3D geological modeling via an analysis of stratigraphic sequence; finally a 3D geological model of Quaternary loose sedimentary strata is constructed using the global discrete control points of each stratum.

\section{Methods}

\subsection{Global Discrete Point Interpolation and Encryption of Quaternary Loose Sedimentary Stratum}

The global discrete points of Quaternary loose sedimentary stratum, which represent the spatial distribution of each stratum in the whole study area, are obtained via interpolation and encryption using limited field data based on geostatistical theories such as Kriging, inverse distance weighting, etc. (Figure 1). In essence, global interpolation and encryption cannot add new stratification information, but it can coordinate the impact of Quaternary stratification data on other locations without geological data in a more scientific way, so as to obtain the globally optimal analysis results.

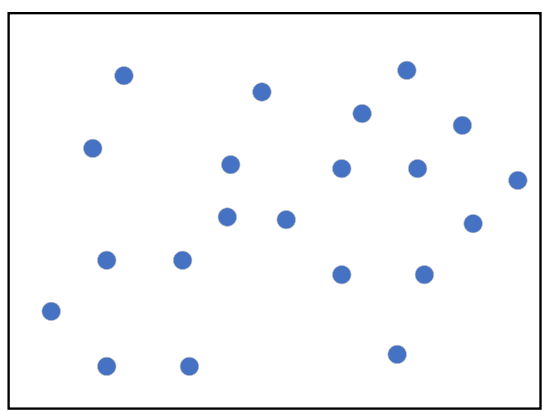

Stratified data of Quaternary strata

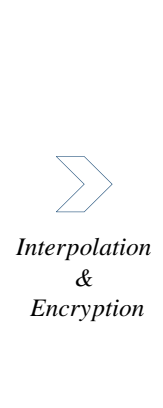

Global control points of Quaternary strata

Figure 1. Technical scheme for the interpolation and encryption of Quaternary stratum. 


\subsection{Analysis of the Stratigraphic Sequence of Quaternary Loose Sedimentary Strata}

The spatial structure characteristics and stratigraphic sequence of Quaternary loose strata are objective and unique, while the geological information acquired from field exploration such as drilling or profiling is only representative of local areas, and only includes fragments of the overall stratigraphic sequence of the study area. Therefore, it is necessary to integrate all of the field exploration data to determine the synthesized stratigraphic sequence of the Quaternary loose sedimentary strata in the whole study area (Figure 2), which can be used as a temporal and spatial framework for stratigraphic spatial structure analysis and stratigraphic sedimentary evolution.

The stratigraphic sequence determines how the contact relationships between strata are to be treated, which controls the spatial structure of Quaternary loose sedimentary strata. The construction of a 3D geological model of Quaternary loose sedimentary strata requires the synthetic stratigraphic sequence of the study area, which can be obtained by integrating the internal sequence information of all geological data.

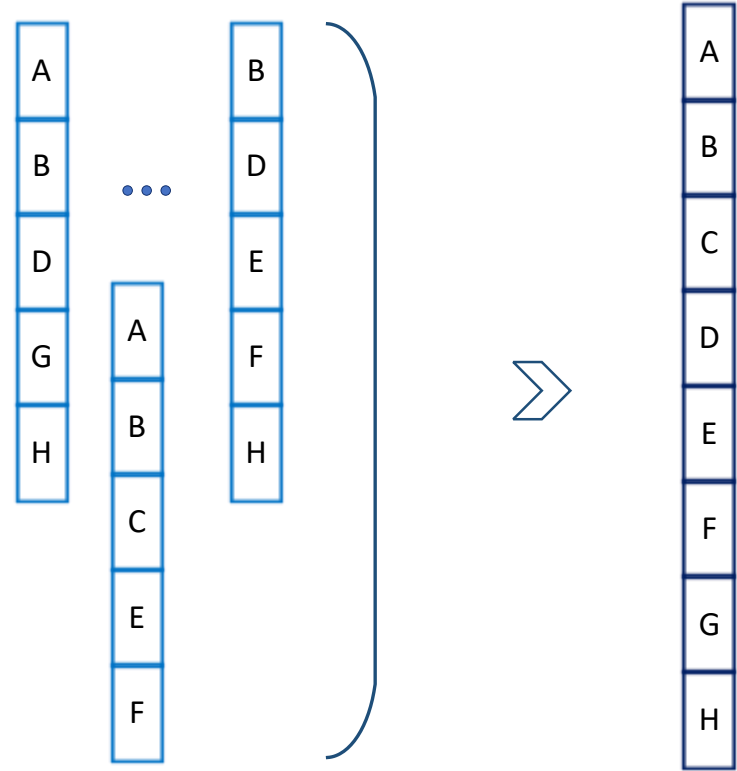

Figure 2. Technical scheme of the synthetic stratigraphic sequence of Quaternary strata.

\subsection{Contact Relationships of Quaternary Loose Sedimentary Strata}

As shown in Figure 3, the different types of contact relationships of Quaternary loose sedimentary strata mainly include conformity, disconformity(para-unconformity), unconformity, erosion, etc. For the construction of a 3D geological model of Quaternary strata, since the stratigraphic sequence is unique, the treatment of disconformable contact relationship is similar to the conformity; regarding unconformity contact, its formation is mainly related to differences in the topography, hydrodynamic conditions, and provenance characteristics of the deposition process, which results in local angular unconformity contact relationships between adjacent strata of different depositional origins, and the stratigraphic sequence is that the old stratum is underneath the new; for erosion contact, the deposition process takes place when part of the old stratum is denuded by erosion due to water or wind flow, and then new sediments fill the eroded area, and hence the stratigraphic sequence is that the new stratum lies beneath the old. The contact relationship is one of the key factors for determining the spatial pattern of the strata. For 3D geological modeling based on the global discrete points, it is necessary to use the 4 types of contact relationships to deal with the intersection modes of adjacent strata. 


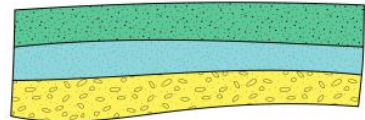

Conformity (Disconformity)

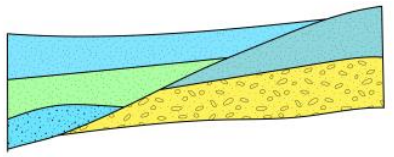

Unconformity

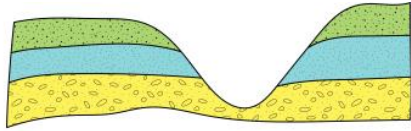

Erosion

Figure 3. Four types of contact relationships of Quaternary strata.

The discrete point set of a stratum obtained by interpolation and encryption is evenly distributed throughout the study area, which results in the control surface generated from it also being globally distributed. Therefore, it is necessary to topologically cut off the redundant part of the stratum according to the intersection mode of the adjacent strata, which is determined by the contact relationship.

As shown in Figure 4, for conformity (disconformity), no special treatment is needed, and the 3D geological model of the stratum will be automatically constructed by tracking the stratigraphic boundary; for unconformity, the underlying old stratum is taken as the basement, and the superfluous parts of the overlying stratum that overlap with the underlying old stratum are cut off, while retaining the other parts that do not overlap with the old; conversely, the erosion contact needs to cut out and delete the parts of the underlying old stratum that overlap with the overlying new one.

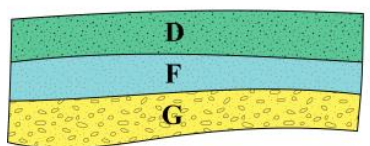

Conformity

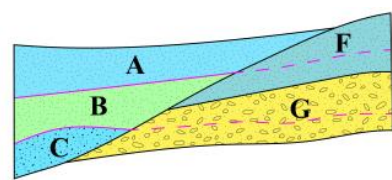

Unconformity

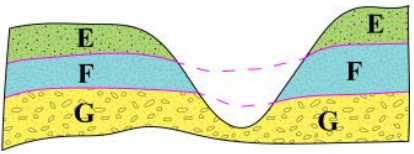

Erosion

Figure 4. Intersection modes of different contact relationships of Quaternary sedimentary strata.

\subsection{Techincal Scheme}

The technical scheme (Figure 5) of the construction of the 3D geological model of Quaternary loose sedimentary strata based on global stratigraphic discrete points obtains a global stratigraphic control point set by applying the geological field data for interpolation and encryption, and generates a control surface for each sedimentary stratum based on this; then, the contact relationships and intersection modes of the strata are determined on the basis of stratigraphic sequence analysis; finally, the construction of the $3 \mathrm{D}$ geological model of the Quaternary loose sedimentary strata can be carried out. 


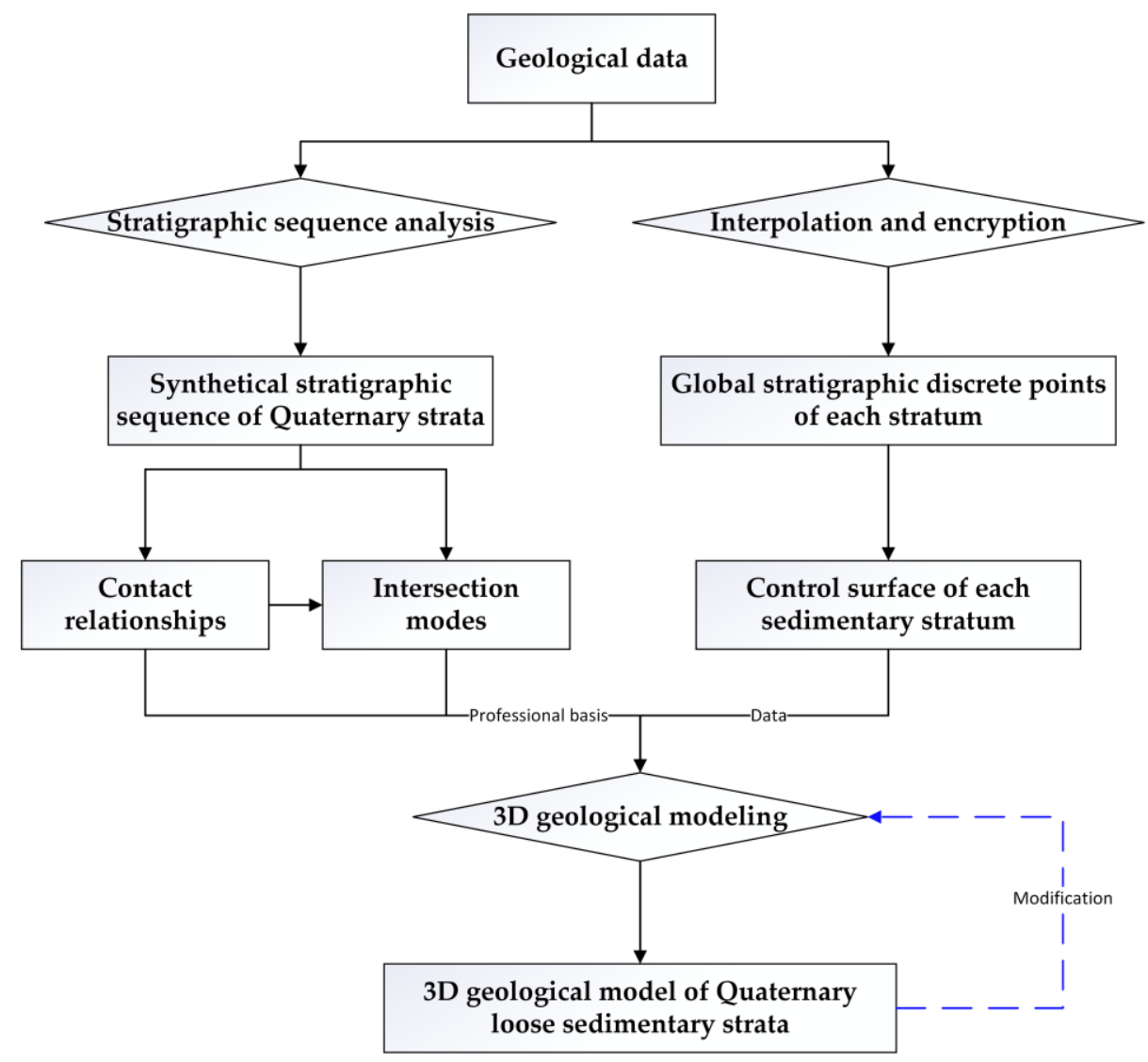

Figure 5. Technical scheme of construction of 3D geological model of Quaternary loose sedimentary strata based on the global stratigraphic discrete points.

\section{Case Study}

\subsection{Study Area}

The study area is located in the citizen center of Xiong'an new area, with an area of approximately $500 \times 600 \mathrm{~m}^{2}$ (Figure 6). There are huge and thick Quaternary loose strata in the area, and their origin is very complex, including the alluvial-proluvial deposits of the Taihang mountains located in the northwest of Xiong'an new area, the floodplain deposits and shallow lacustrine of Baiyangdian lake, as well as fluvial deposits, etc. The modeling scope is a depth of $15 \mathrm{~m}$ below the surface.

\subsection{Modeling Scheme}

This study determined the sedimentary facies information of 81 boreholes with a depth of $15 \mathrm{~m}$ via granulometric analysis and stratigraphic sequence analysis, of which 70 were used as the data to construct a 3D geological structure model of Quaternary loose sedimentary strata, and the other 11 were used as data to verify the model's accuracy. This study mainly used DeepInsight software as the modeling platform, and the specific modeling process was as follows (Figure 7).

(1) Extract the stratification point information of 4 types of sedimentary strata, including the floodplain, alluvial-proluvial, shallow lacustrine, and fluvial, from the borehole;

(2) Obtain the global discrete points of each sedimentary stratum by establishing the Kriging interpolation and encryption model based on Geostatistics theory, which takes the stratification points of each stratum as the sample data;

(3) Generate the constrained surface of each stratum by using the global discrete points;

(4) Determine the contact relationships and intersection modes of the strata by means of stratigraphic sequence analysis; 
(5) Construct the 3D geological model of the Quaternary loose sedimentary strata of the citizen center by utilizing the contact relationships and intersection modes as the modeling basis, the constrained surface as the modeling data, and the DeepInsight software as the modeling platform.

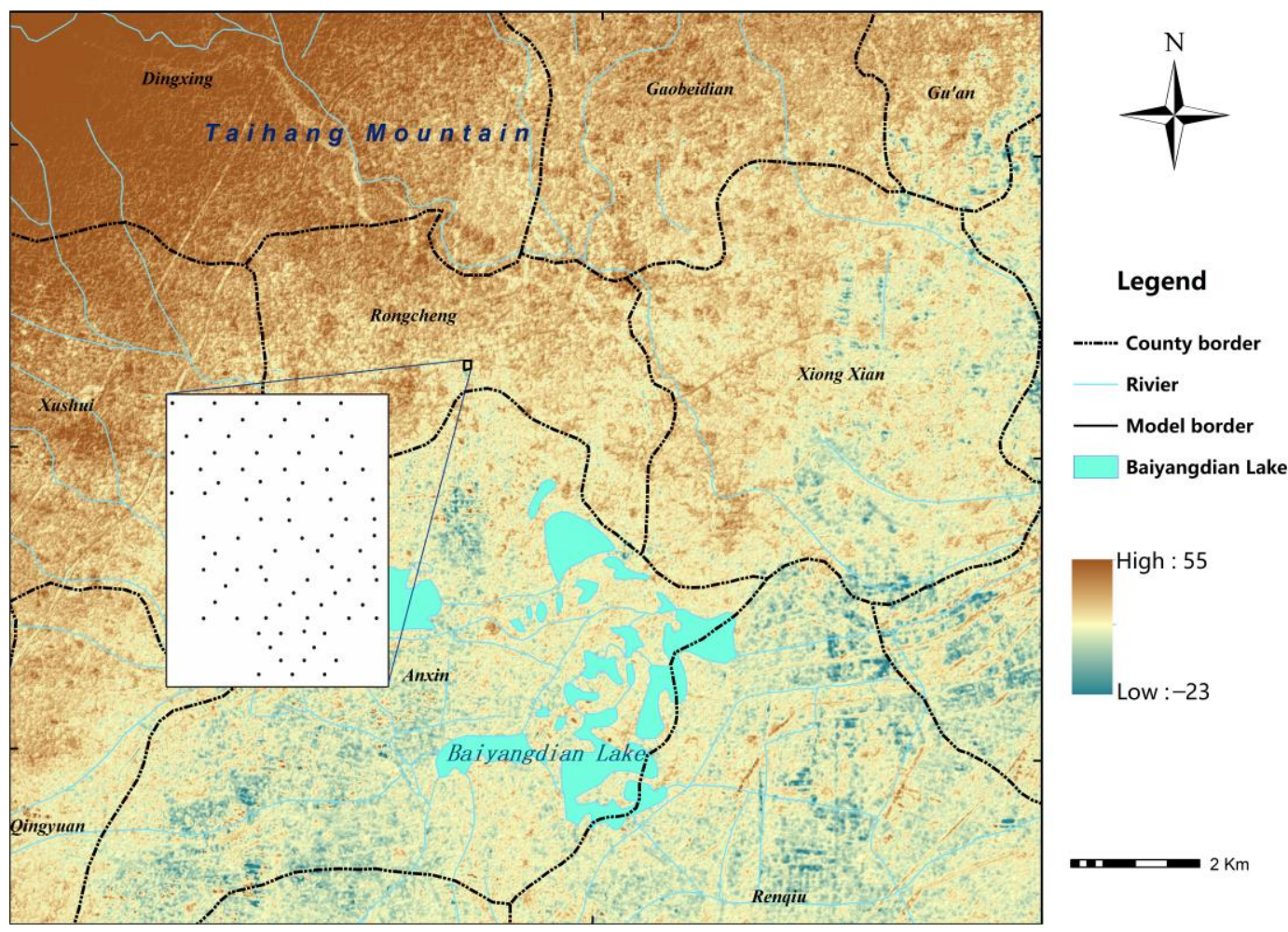

Figure 6. Topography, geomorphology, and distribution of drilling points in the study area.

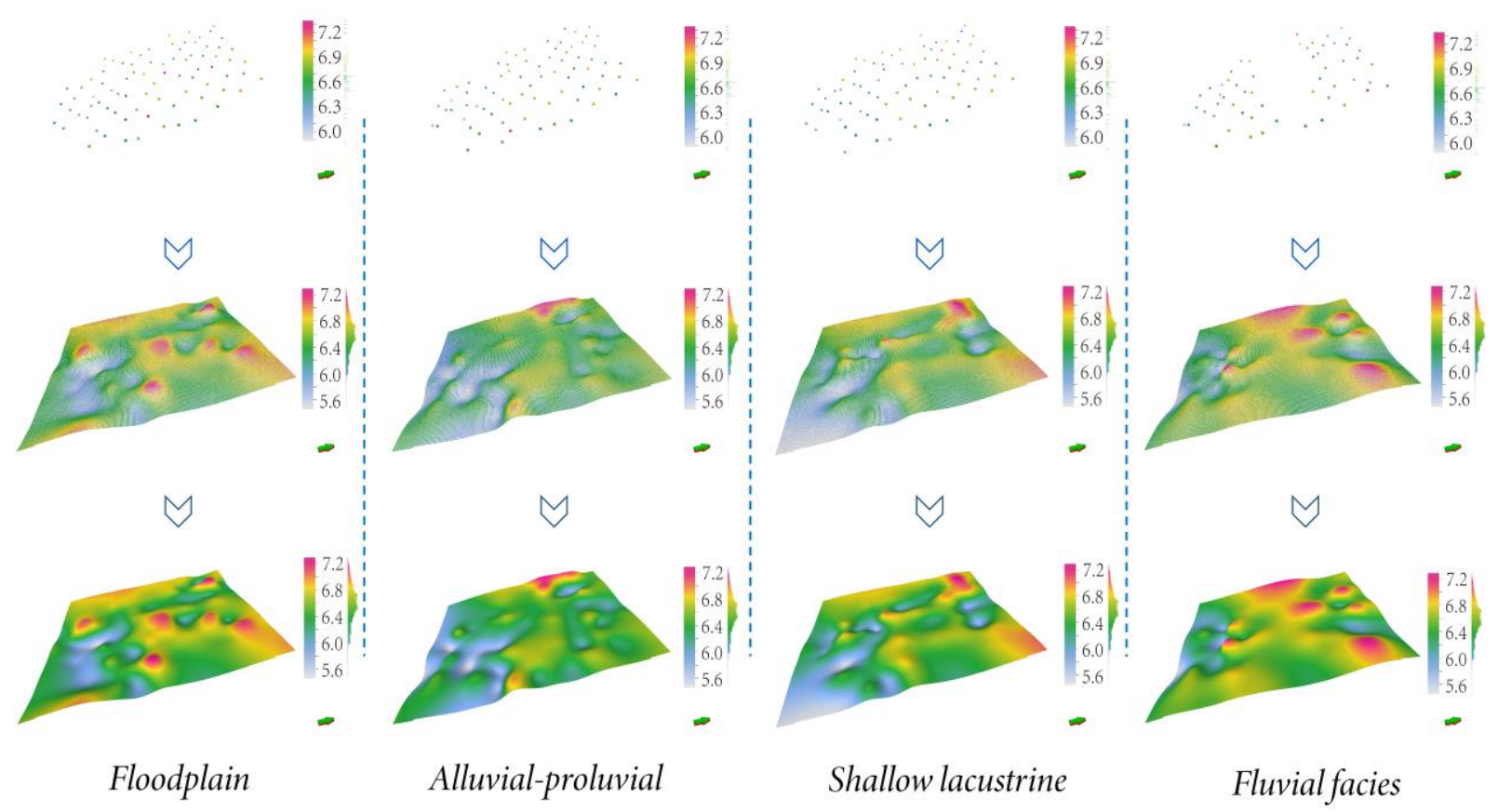

Figure 7. Establishing the 3D geological model of Quaternary loose sedimentary strata of the citizen center based on the global strata discrete points. Vertical exaggeration $=25 \times$. 


\section{Results}

The study area is located at the junction of the margin of the piedmont alluvial fan of the Taihang mountains and the catchment area of Baiyangdian lake, where the terrain is relatively flat and tectonic activity has been quite weak since the Holocene of the Quaternary; hence, there are four types of sedimentary genesis: floodplain, alluvialproluvial, shallow lacustrine and fluvial, from top to bottom. The 3D geological model of the Quaternary loose sedimentary strata of the citizen center is shown in Figure 8.

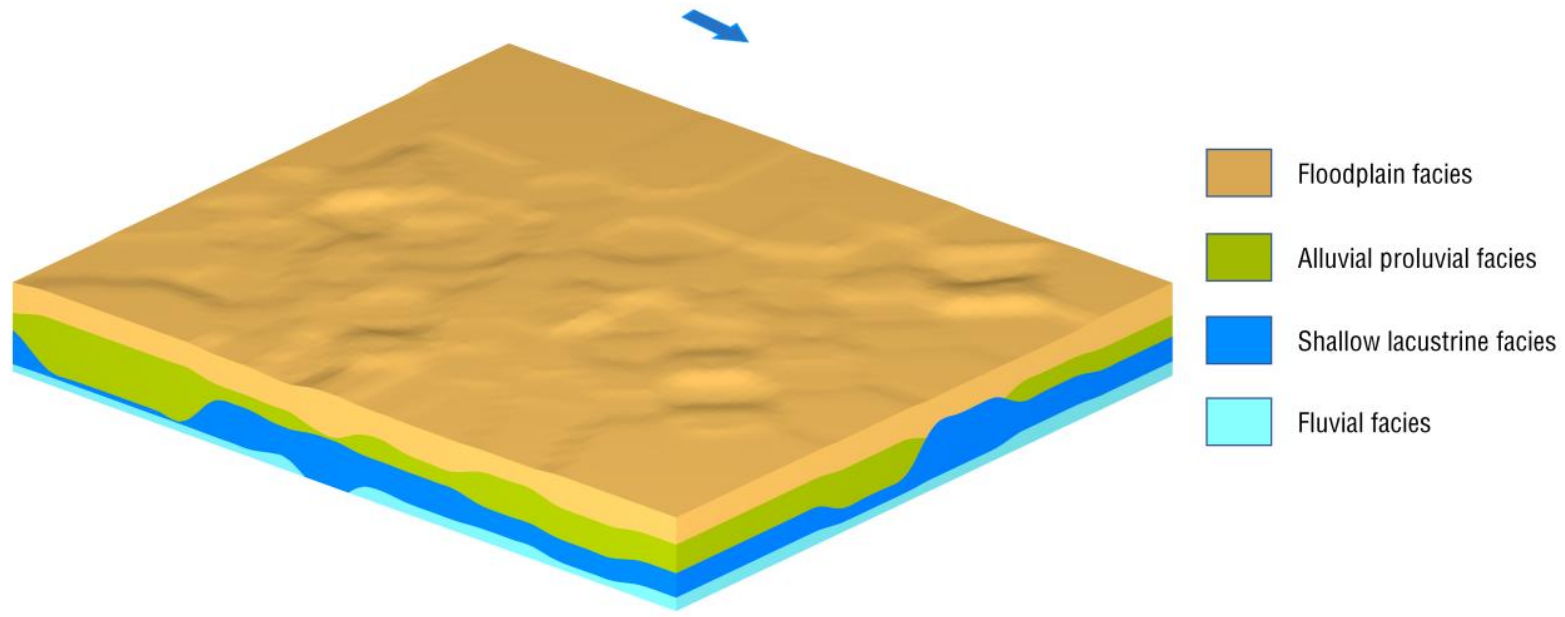

Figure 8. 3D geological model of Quaternary loose sedimentary strata of the study area. Vertical exaggeration $=5 \times$.

According to the results of Quaternary geological exploration, the thickness of the floodplain sedimentary stratum in the study area was about $5 \mathrm{~m}$, was relatively uniform, and covered the whole study area; the alluvial-proluvial sedimentary layer was also the main stratum, and the thickness was about 5-8 m, which varied greatly across the whole area, and even exhibited partial loss in the southwest of the study area; the shallow lacustrine layer covered the whole study area, with the thickness varying sharply between 2 and $8 \mathrm{~m}$, controlled by the evolution of Baiyangdian lake; and the thickness of the fluvial deposit layer, which is dominated by the meandering river sediments, was mostly about 3-6 m, with partial loss in the middle and southwest of the study area (Figure 9).

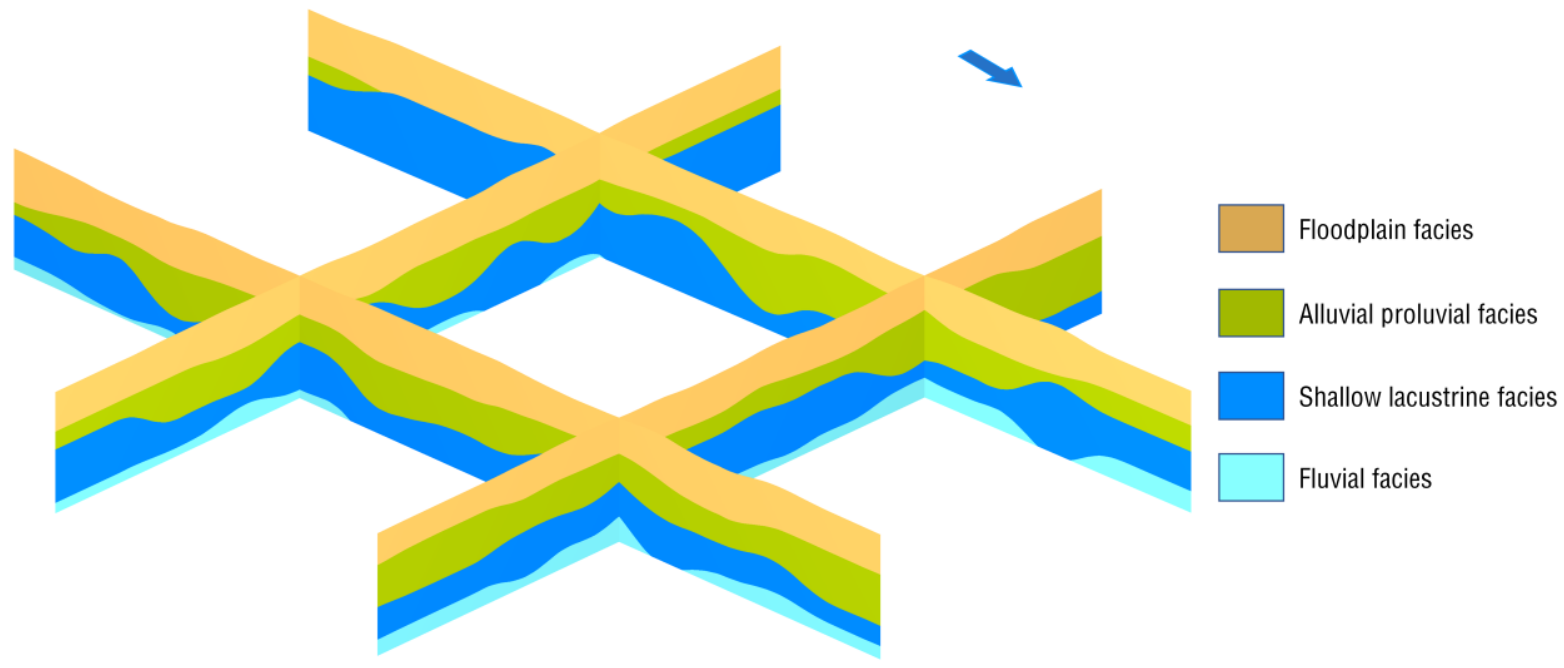

Figure 9. 3D profiles of the sedimentary stratigraphic structure model of the study area. Vertical exaggeration $=5 \times$. 
Finally, we verified the accuracy of the model by means of strata comparison between the virtual boreholes extracted from the model at the same location as the verification drillings and the 11 verification drillings themselves, finding that the accuracy of the model was $92.7 \%$. The verification results show that the modeling approach based on the global strata discrete points is capable of accurately constructing a 3D geological model of Quaternary loose sedimentary strata.

\section{Discussion}

In addition to accurately constructing the 3D model of Quaternary loose sedimentary strata, the most significant application of the 3D geological structure modeling technology based on the global stratigraphical discrete points was the layered simulation of the spatial variation characteristics of the internal properties of strata, such as lithology, porosity, and water content.

Due to the differences in sedimentary genesis, the spatial variation characteristics of lithology, porosity, water content, and the other internal attributes of sedimentary strata will be different. The layered geological structure model is able to simulate the spatial variation characteristics of the internal properties of each stratum individually by using itself as the simulation boundary. Therefore, compared with the overall simulation, the accuracy of the layered simulation is always much higher. To verify it, in this study, we established a lithology model of the study area using the sequential indicators stochastic simulation method based on the Quaternary loose sedimentary strata model (Figure 10), and the levels of accuracy of the lithology model were 93.5\% (floodplain), 95.8\% (alluvial-proluvial), 95.2\% (shallow lacustrine) and 94.1\% (fluvial), which are significantly higher than the 85.3\% achieved by the overall stochastic simulation.

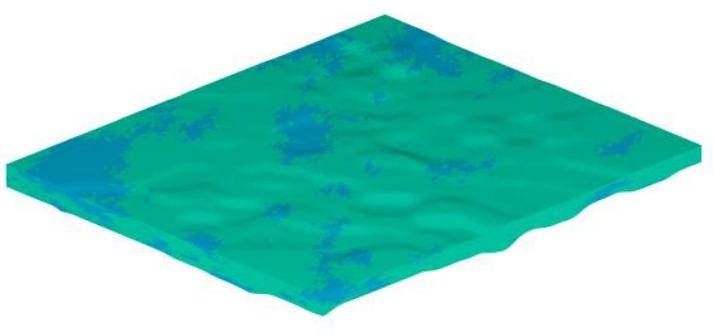

Strata of floodplain

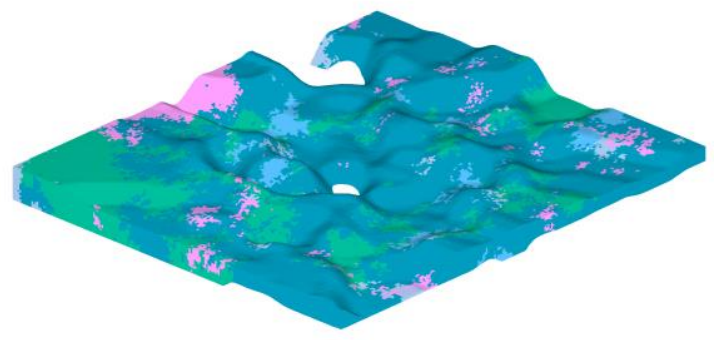

Strata of shallow lacustrine

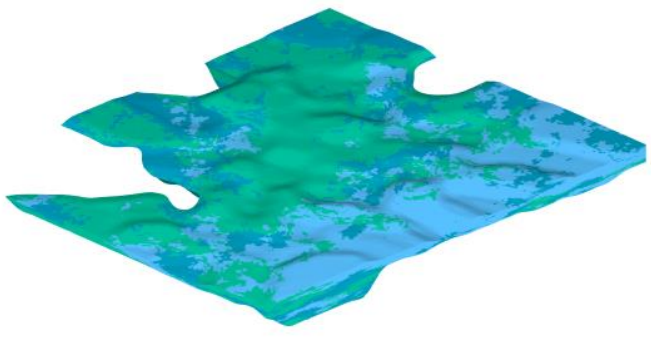

Strata of alluvial proluvial

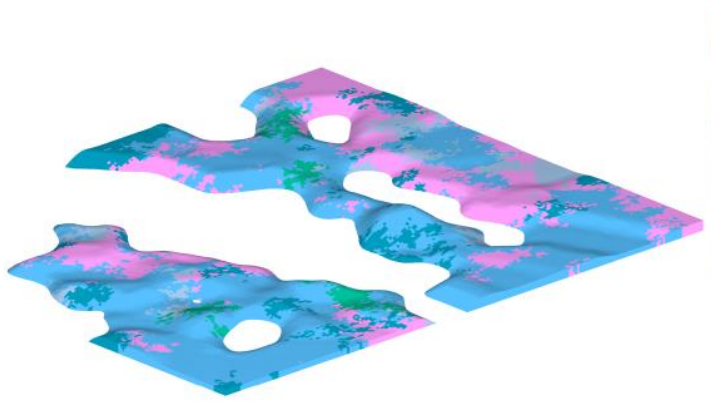

Strata of fluvial silt clay

silt

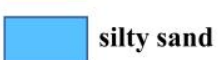

clay

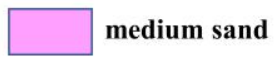

coarse sand

Figure 10. Stratigraphic lithology model of Quaternary loose sedimentary strata in the citizen center based on layered simulation. Vertical exaggeration $=5 \times$.

\section{Conclusions}

The 3D geological modeling of Quaternary loose sedimentary strata based on the global stratigraphic discrete points, which were firstly used to obtain a spatial structure control point set by applying limited field geological data for interpolation and encryption based on Geostatistics theory; then, the contact relationships and intersection modes were 
determined via stratigraphic sequence analysis; and finally a model of the strata was constructed using these as the geological basis.

Taking the citizen center of Xiong'an new area as the study area, this study constructed a 3D geological model of four deposited genetic types of Quaternary loose sedimentary strata, including the floodplain, the piedmont alluvial-proluvial of the Taihang mountains, the shallow lacustrine of Baiyangdian lake, and fluvial, from top to bottom, with a depth of $15 \mathrm{~m}$ from the surface by using the 3D geological modeling approach based on global stratigraphic discrete points. Finally, we evaluated the accuracy $(92.7 \%)$ of the model by extracting virtual boreholes for stratigraphic comparison with the verification boreholes.

The 3D structure model of each sedimentary stratum can be used as a constraint framework to establish a simulation model of the spatial variation of the properties of each stratum, respectively, such as lithology, water content, and porosity. Compared with the overall simulation, analysis results with higher precision were obtained.

Author Contributions: Conceptualization, J.Z. and G.Z.; methodology, J.Z. and Y.L.; software, J.Z. and G.J.; validation, X.Z., Y.L.; formal analysis, Y.L.; investigation, G.Z.; resources, X.Z.; data curation, J.Z.; writing—original draft preparation, J.Z. and G.Z.; writing—review and editing, J.Z. and G.Z.; visualization, J.Z., Y.L. and G.J. supervision, X.Z.; project administration, X.Z.; funding acquisition, X.Z. All authors have read and agreed to the published version of the manuscript.

Funding: This research was funded by Comprehensive Monitoring of Resources and Environment Carrying Capacity of Xiong'an New Area and Construction of Digital Platform of Transparent Xiong'an (Institute of hydrogeology and environmental geology, Chinese Academy of Geological Sciences)(NO.DD20189144) and 3D geological modeling of Multi-factors urban geology of Wuhan (NO. WHDYS-2020-007).

Institutional Review Board Statement: Not applicable.

Informed Consent Statement: Not applicable.

Data Availability Statement: Not applicable.

Conflicts of Interest: The authors declare that they have no conflict of interest.

\section{References}

1. Rohmer, O.; Bertrand, E.; Mercerat, E.D.; Régnier, J.; Alvarez, M. Combining borehole log-stratigraphies and ambient vibration data to build a 3D Model of the Lower Var Valley, Nice (France). Eng. Geol. 2020, 270, 105588. [CrossRef]

2. $\quad$ Price, S.J.; Terrington, R.L.; Busby, J.; Bricker, S.; Berry, T. 3D ground-use optimisation for sustainable urban development planning: A case-study from Earls Court, London, UK. Tunn. Undergr. Sp. Tech. 2018, 81, 144-164. [CrossRef]

3. Guo, J.; Wang, X.; Wang, J.; Dai, X.; Wu, L.; Li, C.; Li, C.; Li, F.; Liu, S.; Jessell, M.W. Three-dimensional geological modeling and spatial analysis from geotechnical borehole data using an implicit surface and marching tetrahedra algorithm. Eng. Geol. 2021, 284, 106047. [CrossRef]

4. Edington, D.; Poeter, E. Stratigraphic Control of Flow and Transport Characteristics. Ground Water 2006, 45, 10-16. [CrossRef]

5. Ghiglieri, G.; Carletti, A.; Pelo, S.D.; Cocco, F.; Funedda, A.; Loi, A. Three-dimensional hydrogeological reconstruction based on geological depositional model: A case study from the coastal plain of arborea (Sardinia, Italy). Eng. Geol. 2016, 207, 103-114. [CrossRef]

6. Hou, W.; Yang, L.; Deng, D.; Ye, J.; Clarke, K.; Yang, Z.; Zhuang, W.; Liu, J.; Huang, J. Assessing quality of urban underground spaces by coupling 3D geological models: The case study of Foshan city, South China. Comput. Geosci. 2016, 89, 1-11. [CrossRef]

7. Dou, F.; Li, X.; Xing, H.; Yuan, F.; Ge, W. 3D geological suitability evaluation for urban underground space development-A case study of QianJiang Newtown in Hangzhou, Eastern China. Tunn. Undergr. Sp. Tech. 2021, 115, 104052. [CrossRef]

8. Giannini, L.M.; Varone, C.; Esposito, C.; Mugnozza, G.S.; Schilir'o, L. The potential of spatial statistics for the reconstruction of a subsoil model: A case study for the Firenze-Prato-Pistoia Basin, Central Italy. J. Appl. Geophy. 2021, 194, 104466. [CrossRef]

9. Chen, Q.; Mariethoz, G.; Liu, G.; Comunian, A.; Ma, X. Locality-based 3-D multiple-point statistics reconstruction using 2-D geological cross sections. Hydrol. Earth Syst. Sci. 2018, 22, 6547-6566. [CrossRef]

10. Mariethoz, G.; Renard, P.; Straubhaar, J. The Direct Sampling method to perform multiple-point geostatistical simulations. Water Resour. Res. 2010, 46, W11536. [CrossRef]

11. Picot, M.; Marsset, T.; Droz, L.; Dennielou, B.; Baudin, F.; Hermoso, M.; De Rafélis, M.; Sionneau, T.; Cremer, M.; Laurent, D. Monsoon control on channel avulsions in the late Quaternary Congo Fan. Quat. Sci. Rev. 2019, 204, 149-171. [CrossRef]

12. Li, Y.; Armitage, S.J.; Stevens, T.; Meng, X. Alluvial fan aggradation/incision history of the eastern tibetan plateau margin and implications for debris flow/debris-charged flood hazard. Geomorphology 2018, 318, 203-216. [CrossRef] 
13. Gao, L.; Long, H.; Tamura, T.; Ye, L.; Shen, J. Refined chronostratigraphy of a late Quaternary Sedimentary sequence from the Yangtze River delta based on K-feldspar luminescence dating. Mar. Geol. 2020, 427, 106271. [CrossRef]

14. Fabbri, S.C.; Buechi, M.W.; Horstmeyer, H.; Hilbe, M.; Hübscher, C.; Schmelzbach, C.; Weiss, B.; Anselmetti, F.S. A subaquatic moraine complex in overdeepened Lake Thun (Switzerland) unravelling the deglaciation history of the Aare Glacier. Quat. Sci. Rev. 2018, 187, 62-79. [CrossRef]

15. Jenner, K.A.; Campbell, D.C.; Piper, D.J.W. Along-slope variations in sediment lithofacies and depositional processes since the last glacial maximum on the northeast Baffin margin, Canada. Mar. Geol. 2018, 405, 92-107. [CrossRef]

16. Chen, H.; Stow, D.A.; Xie, X.; Ren, J.; Mao, K.; Gao, Y.; Van Rooij, D. Depositional architecture and evolution of basin-floor fan systems since the Late Miocene in the Northwest Sub-Basin, South China Sea. Mar. Pet. Geol. 2021, 126, 104803. [CrossRef]

17. Waters, M.R. Alluvial chronologies and archaeology of the Gila River drainage basin, Arizona. Geomorphology 2008, $101,332-341$. [CrossRef]

18. Palmquist, R.C. Alluvial fan sediments and surface ages resulting from differing climatic and tectonic conditions in Star Valley, Wyoming, USA. Catena 2019, 181, 104050. [CrossRef]

19. Fierens, R.; Toucanne, S.; Droz, L.; Jouet, G.; Jorry, S.J. Quaternary sediment dispersal in the Zambezi turbidite system (SW Indian Ocean). Mar. Geol. 2020, 428, 106276. [CrossRef]

20. Berg, F.; Schlunegger, F. Alluvial cover dynamics in response to floods of various magnitudes: The effect of the release of glaciogenic material in a Swiss Alpine catchment. Geomorphology 2012, 141-142, 121-133. [CrossRef]

21. Huelle, D.; Lehmkuhl, F.; Nottebaum, V. Aspects of late Quaternary geomorphological development in the Khangai Mountains and the Gobi Altai Mountains (mongolia). Geomorphology 2018, 312, 24-39.

22. Ibarra-Arzave, G.; Solleiro-Rebolledo, E.; Sanchez, G.; Sedov, S.; Alexandra, G.; Morales, I.S.; Chávez-Vergara, B. Response of surface processes to the Holocene landscape changes in Sonora: Evidences from the paleosol-sedimentary sequences at the archaeological sites Fin del Mundo and gramal. J. South. Am. Earth Sci. 2020, 104, 102947. [CrossRef]

23. Zhu, L.; Pan, X.; Sun, J. Visualization and dissemination of global crustal models on virtual globes. Comput. Geosci. 2016, 90, 34-40. [CrossRef]

24. Pan, D.; Xu, Z.; Lu, X.; Zhou, L.; Li, H. 3D scene and geological modeling using integrated multi-source spatial data: Methodology, challenges, and suggestions. Tunn. Undergr. Sp. Tech. 2020, 100, 103393. [CrossRef]

25. Shishaye, H.A.; Tait, D.R.; Befus, K.M.; Maher, D.T. New insights into the hydrogeology and groundwater flow in the Great Barrier Reef catchment, Australia, revealed through 3D modelling. J. Hydrol. Reg. Stud. 2020, 30, 100708. [CrossRef]

26. Raiber, M.; Webb, J.A.; Cendon, D.I.; White, P.A.; Jacobsen, G.E. Environmental isotopes meet 3D geological modelling: Conceptualising recharge and structurally-controlled aquifer connectivity in the Basalt Plains of South-Western Victoria, Australia. J. Hydrol. 2015, 527, 262-280. [CrossRef]

27. Martinius, A.W.; Ringrose, P.S.; Brostrøm, C.; Elfenbein, C.; Næss, A.; Ringås, J.E. Reservoir challenges of Heterolithic tidal sandstone reservoirs in the Halten Terrace, mid-Norway. Pet. Geosci. 2005, 11, 3-16. [CrossRef]

28. Peeters, J.; Busschers, F.; Stouthamer, E.; Bosch, A.J.; Middelkoop, H. Sedimentary architecture and chronostratigraphy of a late Quaternary incised-valley fill: A case study of the late middle and late Pleistocene Rhine system in the Netherlands. Quat. Sci. Rev. 2016, 131, 211-236. [CrossRef]

29. Godoy, V.A.; Zuquette, L.V.; Gómez-Hernández, J.J. Stochastic analysis of three-dimensional hydraulic conductivity upscaling in a heterogeneous tropical soil. Comput. Geotech. 2018, 100, 174-187. [CrossRef]

30. Stafleu, J.; Maljers, D.; Gunnink, J.L.; Menkovic, A.; Busschers, F.S. 3D modelling of the shallow subsurface of Zeeland, the Netherlands. Neth. J. Geosci. 2011, 90, 293-310. [CrossRef]

31. Gunnink, J.L.; Maljers, D.; Van Gessel, S.F.; Menkovic, A.; Hummelman, H.J. Digital Geological Model (DGM): A 3D raster model of the subsurface of the Netherlands. Neth. J. Geosci. 2013, 92, 33-46. [CrossRef]

32. Tallini, M.; Spadi, M.; Cosentino, D.; Nocentini, M.; Cavuoto, G.; Fiore, V.D. High-resolution seismic reflection exploration for evaluating the seismic hazard in a Plio-Quaternary intermontane basin (L'Aquila downtown, central Italy). Quat. Int. 2019, 532, 34-47. [CrossRef]

33. Høyer, A.S.; JøRgensen, F.; Foged, F.; He, N.X.; Christiansen, A.V. Three-dimensional geological modelling of AEM resistivity data-A comparison of three methods. J. Appl. Geophy. 2015, 115, 65-78. [CrossRef]

34. Lau, J.; Thomason, J.; Malone, D.; Peterson, E. Three-dimensional geological model of quaternary sediments in Walworth County, Wisconsin, USA. Geosciences 2016, 6, 32. [CrossRef]

35. Chen, Q.; Liu, G.; Ma, X.; Li, X.; He, Z. 3D stochastic modeling framework for Quaternary sediments using multiple-point statistics: A case study in MinJiang Estuary area, Southeast China. Comput. Geosci. 2020, 136, 104404. [CrossRef]

36. Erharter, G.H.; Tschuchnigg, F.; Poscher, G. Stochastic 3d modelling of discrete sediment bodies for geotechnical applications. Appl. Comput. Geosci. 2021, 11, 100066. [CrossRef]

37. Srinivasan, S.; O’Malley, D.; Mudunuru, M.K.; Sweeney, M.R.; Hyman, J.D.; Karra, S.; Frash, L.; Carey, J.W.; Gross, M.R.; Guthrie, G.D.; et al. A machine learning framework for rapid forecasting and history matching in unconventional reservoirs. Sci. Rep. 2021, 11, 21730. [CrossRef] 
38. Mudunuru, M.K.; O’Malley, D.; Srinivasan, S.; Hyman, J.D.H.; Sweeney, M.R.; Frash, L.P.; Carey, J.W.; Gross, M.R.; Welch, N.J.; Karra, S.; et al. Physics-Informed Machine Learning for Real-Time Unconventional Reservoir Management (No. LA-UR-19-31611); Los Alamos National Lab.(LANL): Los Alamos, NM, USA, 2020. Available online: https:/ / permalink.lanl.gov/object/tr?what=info: lanl-repo/lareport/LA-UR-19-31611 (accessed on 28 December 2021).

39. Mudunuru, M.K.; Karra, S.; Makedonska, N; Chen, T. Sequential geophysical and flow inversion to characterize fracture networks in subsurface systems. Stat. Anal. Data Min. ASA Data Sci. J. 2017, 10, 326-342. [CrossRef]

40. Ito, Y.; Oguchi, T.; Masuda, F. Late Quaternary depositional sequences and landforms in relation to sea-level changes in the Osaka intra-arc basin, Japan: A borehole database analysis. Quat. Int. 2018, 471, 298-317. [CrossRef]

41. Lang, J.; Sievers, J.; Loewer, M.; Igel, J.; Winsemann, J. 3D architecture of cyclic-step and antidune deposits in glacigenic subaqueous fan and delta settings: Integrating outcrop and ground-penetrating radar data. Sediment. Geol. 2017, 362, 83-100. [CrossRef]

42. López-Quirós, A.; Lobo, F.J.; Duffy, M.; Leventer, A.; Evangelinos, D.; Escutia, C.; Bohoyo, F. Late Quaternary high-resolution seismic stratigraphy and core-based paleoenvironmental reconstructions in Ona Basin, southwestern Scotia Sea (Antarctica). Mar. Geol. 2021, 439, 106565. [CrossRef]

43. Cheng, C.; Jiang, T.; Kuang, Z.; Ren, J.; Liang, J.; Lai, H.; Xiong, P. Seismic characteristics and distributions of Quaternary mass transport deposits in the Qiongdongnan Basin, northern South China Sea. Mar. Pet. Geol. 2021, 129, 105118. [CrossRef] 